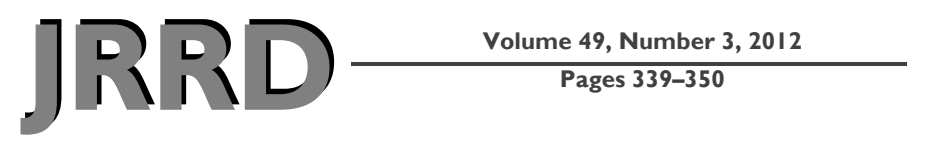

\title{
Preventive services in veterans in relation to disability
}

\author{
Alyson J. Littman, PhD, MPH; ${ }^{1-2 *}$ Thomas D. Koepsell, MD, MPH; ${ }^{1-3}$ Christopher W. Forsberg, MS; ${ }^{1}$ Jodie K. $^{2}$ \\ Haselkorn, MD, MPH; ${ }^{2,4-5}$ Edward J. Boyko, MD, MPH ${ }^{1}$ \\ ${ }^{1}$ Epidemiologic Research and Information Center, Department of Veterans Affairs (VA) Puget Sound Health Care Sys- \\ tem, Seattle, WA; Departments of ${ }^{2}$ Epidemiology, ${ }^{3}$ Health Services, and ${ }^{4}$ Rehabilitation Medicine, University of Wash- \\ ington, Seattle, WA; ${ }^{5}$ Multiple Sclerosis Center of Excellence West, VA Puget Sound Health Care System, Seattle WA
}

\begin{abstract}
Veterans with disabilities are at an increased risk of secondary impairments and may have difficulty accessing preventive services; accessibility may differ between Veterans who do and do not receive care at Department of Veterans Affairs (VA) facilities. We used data from the 2003 and 2004 Behavioral Risk Factor Surveillance System surveys to evaluate associations between disability and receipt of preventive services in Veterans. Veterans with a disability were more likely to have received influenza vaccinations (VA users and nonusers), pneumococcal vaccinations (VA nonusers: $p<$ 0.001; VA users: $p=0.073$ ), weight management counseling (VA nonusers: $p<0.001$; male VA users: $p<0.001$ ), lower gastrointestinal (GI) endoscopy (VA nonusers: 50-64 yr, $p=0.03$; VA users: $\geq 65 \mathrm{yr}, p=0.085$ ), mammography (VA users: $p=$ 0.097), and serum cholesterol screening (VA nonusers: $p<$ 0.001 ). Receipt was similar by disability status for fecal occult blood test (FOBT), lower GI endoscopy (VA users: 50-64 yr), human immunodeficiency virus testing, and cervical cancer screening. For no measure was there significantly lower receipt in those with versus without a disability, although there was marginal evidence in VA nonusers for overall colorectal cancer screening (i.e., lower GI endoscopy or FOBT: $p=0.063$ ). Among Veterans, having a disability did not appear to be a barrier to receiving appropriate preventive care.
\end{abstract}

Key words: cervical cancer screening, colon cancer screening, Department of Veterans Affairs, disability, prevention, preventive medicine, primary prevention, vaccination, Veterans, women's health.

\section{INTRODUCTION}

To increase longevity and improve quality of life, the National Center for Health Statistics set goals for delivery of several preventive health services considered to be of proven effectiveness, including pneumococcal and influenza vaccinations; colorectal, breast, and cervical cancer screening; human immunodeficiency virus (HIV) testing; weight management counseling; and cholesterol screening [1]. Eliminating health disparities was a second goal, including disparities between persons with and without disabilities. The extent to which disparities in preventive health services exist among Veterans in relation to disability has not previously been studied.

The Department of Veterans Affairs (VA) operates the largest integrated healthcare system in the United States, serving over 5.5 million people or about 20 percent of all Veterans [2]. Those with a service-connected disability

\footnotetext{
Abbreviations: BRFSS $=$ Behavioral Risk Factors Surveillance System, CDC = Centers for Disease Control and Prevention, $\mathrm{FOBT}=$ fecal occult blood test, GI = gastrointestinal, HIV = human immunodeficiency virus, VA $=$ Department of Veterans Affairs.

*Address all correspondence to Alyson J. Littman, PhD, MPH; Epidemiologic Research and Information Center, VA Puget Sound Medical Center, 1100 Olive Way, Metropolitan Park West, Suite 1400, Seattle, WA 98101; 206-2774182; 206-764-2563. Email: alyson@u.washington.edu http://dx.doi.org/10.1682/JRRD.2010.12.0229
} 
have the highest priority for VA care and many also qualify for cost-free healthcare services [3]. Beginning in 1995, the VA instituted healthcare delivery reforms involving numerous quality improvement initiatives, including implementing a systematic approach to healthcare delivery and quality evaluation. These initiatives focused on both measuring quality and holding managers accountable for meeting quality goals by tracking performance measures [4-5]. Performance measures of quality of care have included assessing the percentage of patients who have been screened for breast, cervical, and colorectal cancers and high cholesterol and have received influenza and pneumococcal vaccinations. These performance measures, along with numerous other advances including electronic medical records and computerized clinical reminders, are thought to have helped increase preventive care delivery within the VA. For example, the frequency of pneumococcal vaccination for eligible VA patients rose from 28 percent during the mid-1990s to 85 percent by 2003 [6], exceeding the frequencies observed in individuals receiving care outside the VA system [7-8].

In non-VA settings, a number of studies have found disparities in receipt of preventive care in relation to disability [9-15]. The most consistent findings have been higher rates of vaccination $[10,13]$ and lower rates of cervical cancer screening (i.e., Pap test) [9-13,16-18] among persons with a disability. Findings for mammography have been variable. Some studies have reported lower rates of mammography in persons with a disability [9-13,16-18], while others have found no difference or even greater receipt [10,19-20]. However, no recent studies have determined whether such disparities exist among Veterans or within the VA, where only about 5 to 10 percent of patients are women. In an effort to provide sexspecific and sex-sensitive services in a system historically focused on treating men, many VA facilities have created separate women's clinics [21]. It is often in these clinics, when present, rather than with their primary care provider that women receive Pap tests. The need to make an additional visit to a separate clinic may create a barrier to care for female VA users with a disability. The studies that have evaluated rates of colorectal cancer screening by the presence or absence of a disability have been inconsistent [12,14-15]. Few studies have investigated differences in receipt of HIV testing and weight management counseling in relation to disability [22-23].

Persons with a disability may receive less preventive care because of structural (e.g., equipment or offices that are not accessible [24]), provider (e.g., lack of time, attention, provider knowledge, or failure to prioritize chronic disease prevention [25-26]), and patient (e.g., lack of awareness of need for preventive services [27]) factors. Conversely, people with a disability may have more frequent interactions with medical professionals, possibly providing more opportunities to receive immunizations and other services for which a separate appointment is not necessary.

Many Veterans with disabilities, particularly VA users, have complex health histories such as physical and mental health disorders and alcohol and/or substance abuse and misuse that may render them at increased risk of diseases [28-29]. These same conditions may present unique barriers to receiving preventive services. The Behavioral Risk Factor Surveillance System (BRFSS) survey affords a unique opportunity to examine receipt of preventive care in a large population-based sample of VA users and nonusers while employing standard assessment methods in the different populations. The purpose of this study was to examine whether the receipt of preventive healthcare services in Veterans differed based on the presence of a disability in those who received none or some of their healthcare at VA medical centers. Evaluating whether differences exist in the receipt of recommended preventive services is an essential first step prior to developing interventions aimed at achieving equity, minimizing secondary limitations in activity and social participation, and improving the quality of care for all.

\section{METHODS}

The BRFSS survey is carried out collaboratively by the Centers for Disease Control and Prevention (CDC) and by all U.S. state and territorial health departments. The target population is all civilian, noninstitutionalized adults ( $\geq 18$ years old) living in households and having a landline telephone. Each state health department conducts the BRFSS telephone survey in its own state, following sampling protocols and using survey content coordinated and standardized by the CDC. States may augment sample size and add survey content to meet local needs. We used data from the 2003 and 2004 BRFSS surveys, the most recent years when questions on VA healthcare usage were included in the core component of the questionnaire and thus were available on the full sample. 
The BRFSS survey collected information on sociodemographic characteristics (e.g., age, education, and race/ ethnicity), health conditions and status (self-rated health, doctor-diagnosed diabetes, hypercholesterolemia, and hypertension), and smoking, among other characteristics. Health status was assessed by asking respondents to report whether they would say that, in general, their health was excellent, very good, good, fair, or poor. Respondents were asked to report the number of days during the past 30 that their physical health was not good. Physical health was described as including physical illness or injury. A similar question was asked regarding mental health, which was described as including "stress, depression, or problems with emotions.” Healthcare coverage was described as including "health insurance, prepaid plans such as HMOs [health maintenance organizations], or government plans such as Medicare." To assess chronic illnesses, the survey interviewers asked respondents whether a doctor, nurse, or other health professional ever told them that they had diabetes, hypertension, high cholesterol, asthma, or "some form of arthritis, rheumatoid arthritis, gout, lupus or fibromyalgia." The exact wording of questions and more detailed information on the BRFSS survey administration can be found elsewhere [30-32].

We classified individuals as having a disability if they reported being limited in activities because of physical, mental, or emotional problems or if they reported having a health problem that required them to use special equipment such as a cane, wheelchair, special bed, or special telephone. This operational definition of disability has been used previously [33-36] and is consistent with the definition of disability from the National Center for Health Statistics [1]. We classified respondents as Veterans if they reported ever serving on Active Duty in the U.S. Armed Forces, either in the regular military, National Guard, or Reserves, and were currently retired or discharged from the military. We further classified Veterans based on their use of VA facilities for healthcare by asking "In the last 12 months have you received some or all of your health care from VA facilities?” Response options include "Yes, all of my health care," "Yes, some of my health care," and "No, no VA health care received." We classified individuals as VA users if they reported receiving all or some of their healthcare from VA facilities or as VA exclusive users if they reported receiving all of their healthcare from VA facilities. VA nonusers were defined as Veterans who reported receiving none of their care from the VA in the previous 12 months.

We examined self-reports of nine preventive services (influenza and pneumococcal vaccination, weight management counseling, lower gastrointestinal [GI] endoscopy [sigmoidoscopy or colonoscopy, asked as a single question], mammography, Pap test, fecal occult blood test [FOBT], serum cholesterol screening, and HIV testing). We also assessed receipt of a composite measure of colorectal cancer screening, which required that individuals either have had an FOBT in the past year or a lower GI endoscopy in the previous 10 years. Table 1 gives details on eligibility criteria, time interval, year(s) in which data were collected, and sample size for each preventive service. We based inclusion criteria for each preventive service on recommendations in place at the time of the BRFSS survey (2003 and 2004) by the U.S. Preventive Services Task Force and the Advisory Committee on Immunization Practices, organizations comprised of independent panels of experts in primary care and prevention that systematically review the evidence of effectiveness and develop recommendations. As the target age range for mammography within the VA in 2004 (based on the performance measure) was 50 to 69 years, we conducted sensitivity analyses to evaluate receipt in this subpopulation.

The CDC assigned each respondent a final sampling weight. This weight was based in part on each respondent's overall probability of selection and includes a poststratification factor to ensure that the weighted sample agreed with population estimates from the U.S. Census Bureau, thus adjusting in part for demographic differences in probability of selection and nonresponse. Depending on the state, poststratification in BRFSS surveys was performed based on the age- and sex- or the age-, sex-, and race/ethnicity-distribution. We can interpret the value of the weight for each person in the sample as the estimated number of people that he or she represented in the target population. We estimated population sizes and the distribution of sociodemographic and health status characteristics (Table 1) from these weights.

To estimate the prevalence of preventive health services receipt while adjusting for differences in sociodemographic characteristics and healthcare coverage between groups, we used model-based direct rate adjustment [37] to the distribution of all Veterans. We adjusted prevalence estimates for age group, sex, education, marital status, race/ethnicity, having healthcare coverage, and having more than one personal doctor or healthcare provider 
Table 1.

Definitions and sample sizes of preventive healthcare services in Veterans, Behavioral Risk Factors Surveillance System (BRFSS) survey (2003 and 2004).

\begin{tabular}{|c|c|c|c|c|c|}
\hline \multirow{2}{*}{$\begin{array}{c}\text { Preventive Healthcare } \\
\text { Service }\end{array}$} & \multirow{2}{*}{$\begin{array}{l}\text { Characteristics of } \\
\text { Persons Considered } \\
\text { Eligible for Service }\end{array}$} & \multirow{2}{*}{$\begin{array}{c}\text { Time } \\
\text { Interval }\end{array}$} & \multicolumn{3}{|c|}{ No. of Respondents Eligible for Preventive Healthcare Service } \\
\hline & & & VA Nonusers & VA Users & Exclusive VA Users \\
\hline $\begin{array}{l}\text { Influenza } \\
\text { Vaccination }^{*}[1]\end{array}$ & $\begin{array}{l}\geq 50 \text { yr ( } \geq 18 \text { yr if pregnant, } \\
\text { with diabetes, or asthma) }\end{array}$ & Past year & 45,438 & 12,514 & 5,483 \\
\hline $\begin{array}{l}\text { Pneumococcal } \\
\text { Vaccination }^{*}[1]\end{array}$ & $\begin{array}{l}\geq 65 \text { yr ( } \geq 50 \text { yr if with } \\
\text { diabetes) }\end{array}$ & Ever & $\begin{array}{l}\text { 50-64 yr: 2,130; } \\
\geq 65 \text { yr: 22,191 }\end{array}$ & $\begin{array}{l}\text { 50-64 yr: } 988 \\
\geq 65 \text { yr: } 7,183\end{array}$ & $\begin{array}{l}50-64 \text { yr: } 577 \\
\geq 65 \text { yr: } 2,578\end{array}$ \\
\hline $\begin{array}{l}\text { Fecal Occult Blood } \\
\text { Test }^{\dagger}[2]\end{array}$ & $\geq 50 \mathrm{yr}$ & Past year & 27,373 & 7,742 & 3,262 \\
\hline $\begin{array}{l}\text { Lower Gastrointestinal } \\
\text { Endoscopy }^{\dagger}[2]\end{array}$ & $\geq 50 \mathrm{yr}$ & Past $10 \mathrm{yr}$ & $\begin{array}{l}\text { 50-64 yr: } \\
\text { 13,025; } \\
\geq 65 \text { yr: } 14,294\end{array}$ & $\begin{array}{l}\text { 50-64 yr: 3,027; } \\
\geq 65 \text { yr: 4,667 }\end{array}$ & $\begin{array}{l}\text { 50-64 yr: } 1,671 \\
\geq 65 \text { yr: } 1,563\end{array}$ \\
\hline $\begin{array}{l}\text { Cholesterol } \\
\text { Screening }^{\ddagger}[3]\end{array}$ & $\begin{array}{l}\text { Male: } \geq 35 \text { yr; } \\
\text { Female: } \geq 45 \text { yr } \\
\text { ( } \geq 18 \text { yr if with hypercho- } \\
\text { lesterolemia or } \\
\text { hypertension) }\end{array}$ & Past 5 yr & 28,579 & 6,919 & 3,184 \\
\hline $\begin{array}{l}\text { Weight Management } \\
\text { Couseling }{ }^{\ddagger}\end{array}$ & BMI: $\geq 30 \mathrm{~kg} / \mathrm{m}^{2}$ & Past year & $\begin{array}{l}\text { Male: 5,879; } \\
\text { Female: } 444\end{array}$ & $\begin{array}{l}\text { Male:1,541; } \\
\text { Female: } 143\end{array}$ & $\begin{array}{l}\text { Male: } 756 ; \\
\text { Female: } 82\end{array}$ \\
\hline HIV Test ${ }^{*}[4]$ & $<65 \mathrm{yr}$ & Ever & 33,642 & 6,619 & 3,567 \\
\hline Mammography $^{\dagger}[5]$ & Female: $\geq 40$ yr & Past 2 yr & 2,050 & 530 & 287 \\
\hline Pap Test ${ }^{\dagger}[6]$ & Female: 21-64 yr & Past 3 yr & 1,761 & 374 & 219 \\
\hline $\begin{array}{l}\text { Note: BRFSS survey responde } \\
\text { VA nonusers }(n=58,436): 50- \\
\text { VA users }(n=14,419): 50-64 \\
\text { Exclusive VA users }(n=6,476 \\
{ }^{*} \text { Asked in } 2003 \text { and } 2004 \text {. } \\
{ }^{\dagger} \text { Asked in } 2004 \text { only. }\end{array}$ & $\begin{array}{l}\text { nts in each subgroup (not all numb } \\
-64 \mathrm{yr}(n=35,126) \text { and } \geq 65 \mathrm{yr}(n= \\
\mathrm{yr}(n=6,978) \text { and } \geq 65 \mathrm{yr}(n=7,40 \\
): 50-64 \mathrm{yr}(n=3,785) \text { and } \geq 65 \mathrm{yr}\end{array}$ & $\begin{array}{l}\text { 23, sum total be } \\
\text { 23,083); male ( } \\
n=2,673) \text {; mal }\end{array}$ & $\begin{array}{l}\text { cause for some services, ind } \\
n=53,934) \text { and female }(n= \\
, 363) \text { and female }(n=1,056 \\
\text { le }(n=5,902) \text { and female ( } n\end{array}$ & $\begin{array}{l}\text { iduals }<50 \text { years of age } \\
4,502) . \\
574) .\end{array}$ & were eligible)- \\
\hline \multicolumn{6}{|c|}{$\begin{array}{l}\text { 1. Centers for Disease Control and Prevention (CDC). Recommended adult immunization schedule—United States, 2002-2003. MMWR Morb Mortal Wkly Rep. } \\
\text { 2002;51(40):904-8. }\end{array}$} \\
\hline \multicolumn{6}{|c|}{$\begin{array}{l}\text { 2. Summaries for patients. Screening for colorectal cancer: Recommendations from the United States Preventive Services Task Force. Ann Intern Med. } \\
\text { 2002;137(2):I38. }\end{array}$} \\
\hline \multicolumn{6}{|c|}{$\begin{array}{l}\text { 3. U.S. Preventive Services Task Force. Screening for lipid disorders in adults. Recommendation statement. Rockville (MD): U.S. Preventive Services Task Force; } \\
2008 \text { [updated } 2008 \text { Jun]. Available from: http://www.uspreventiveservicestaskforce.org/uspstf08/lipid/lipidrs.htm }\end{array}$} \\
\hline \multicolumn{6}{|c|}{$\begin{array}{l}\text { 4. Branson BM, Handsfield HH, Lampe MA, Janssen RS, Taylor AW, Lyss SB, Clark JE. Revised recommendations for HIV testing of adults, adolescents, and } \\
\text { pregnant women in health-care settings. MMWR Recomm Rep. 2006;55(RR-14):1-17. }\end{array}$} \\
\hline \multirow{2}{*}{\multicolumn{6}{|c|}{$\begin{array}{l}\text { 5. U.S. Preventive Services Task Force. Screening for breast cancer. Rockville (MD): U.S. Preventive Services Task Force; } 2009 \text { [updated } 2010 \text { Jul]. Available } \\
\text { from: http://www.uspreventiveservicestaskforce.org/uspstf/uspsbrca.htm } \\
\text { 6. U.S. Preventive Services Task Force. Screening for cervical cancer. Rockville (MD): U.S. Preventive Services Task Force; } 2003 \text { [updated } 2009 \text { Dec]. Available } \\
\text { from: http://www.uspreventiveservicestaskforce.org/uspstf/uspscerv.htm }\end{array}$}} \\
\hline & & & & & \\
\hline & & & & & \\
\hline
\end{tabular}

(using the categories for each variable as presented in Table 2). Pearson chi-square tests corrected for the survey design [38] and converted into an F-statistic were used to calculate $p$-values for differences in the receipt of preventive health services by disability. In addition, we evaluated whether differences existed in the association between disability and receipt of each service by sex and age by including interaction terms of disability $\times$ sex and disabil- ity $\times$ age (e.g., 50-64 vs $\geq 65$ years). If the $p$-value for the interaction was statistically significant $(p<0.05)$, we present sex- and/or age-stratified results. As systematic differences may exist between Veterans who receive all (exclusive VA users) versus only some of their care at the VA, we also conducted analyses in the former group. We conducted analyses using the svy (survey) commands in Stata 11.1 (Stata Corp; College Station, Texas). 
Table 2.

Sociodemographic characteristics, healthcare, and health conditions of Veterans, Behavioral Risk Factors Surveillance System (BRFSS) survey (2003 and 2004), $n^{*}(\%)$.

\begin{tabular}{|c|c|c|c|}
\hline Characteristic & VA Nonusers & VA Users (all) & Exclusive VA Users \\
\hline \multicolumn{4}{|l|}{ Sociodemographic Characteristic } \\
\hline \multicolumn{4}{|l|}{ Age (yr) } \\
\hline 35-49 & 4.82 (19.9) & $0.75(14.5)$ & $0.38(17.0)$ \\
\hline $50-64$ & $8.34(34.4)$ & $1.64(31.6)$ & $0.90(40.2)$ \\
\hline$\geq 65$ & 8.95 (36.9) & $2.46(47.4)$ & $0.79(35.3)$ \\
\hline Male & $22.84(94.1)$ & $4.89(94.2)$ & 2.09 (93.3) \\
\hline Female & $1.43(5.9)$ & $0.30(5.8)$ & $0.15(6.7)$ \\
\hline \multicolumn{4}{|l|}{ Race/Ethnicity } \\
\hline White (non-Hispanic) & $19.85(81.8)$ & $3.84(74.0)$ & $1.51(67.4)$ \\
\hline Black (non-Hispanic) & $1.77(7.3)$ & 0.67 (12.9) & $0.38(17.0)$ \\
\hline High school graduate & 7.26 (29.9) & $1.60(30.8)$ & $0.73(32.6)$ \\
\hline Some college & $7.16(29.5)$ & $1.70(32.8)$ & $0.76(33.6)$ \\
\hline College graduate & $8.45(34.8)$ & $1.33(25.6)$ & $0.46(20.5)$ \\
\hline \multicolumn{4}{|l|}{ Marital Status } \\
\hline Married or living as married & $18.15(74.8)$ & $3.48(67.1)$ & $1.33(59.4)$ \\
\hline Never married & $1.55(6.4)$ & $0.37(7.1)$ & $0.20(8.9)$ \\
\hline Divorced or separated & $2.96(12.2)$ & $0.91(17.5)$ & $0.53(23.7)$ \\
\hline Widowed & $1.60(6.6)$ & $0.43(8.3)$ & $0.18(8.0)$ \\
\hline \multicolumn{4}{|l|}{ Healthcare and Health Conditions } \\
\hline \multicolumn{4}{|c|}{ Personal doctor/healthcare provider } \\
\hline Excellent & $4.64(19.1)$ & $0.59(11.4)$ & $0.26(11.6)$ \\
\hline Very good & $7.91(36.6)$ & $1.18(22.7)$ & $0.48(21.4)$ \\
\hline Good & $7.67(31.6)$ & $1.72(33.1)$ & $0.72(32.1)$ \\
\hline Fair & $2.86(11.8)$ & $1.08(20.8)$ & $0.48(21.4)$ \\
\hline Poor & 1.19 (4.9) & 0.62 (11.9) & $0.30(13.4)$ \\
\hline \multicolumn{4}{|l|}{ Frequent Poor Physical Health ${ }^{\dagger}$} \\
\hline No & $21.47(88.5)$ & 3.99 (76.9) & $1.67(74.6)$ \\
\hline Yes & $2.80(11.5)$ & 1.19 (22.9) & $0.57(25.4)$ \\
\hline \multicolumn{4}{|l|}{ Frequent Poor Mental Health ${ }^{\dagger}$} \\
\hline No & 22.55 (92.9) & $4.52(87.1)$ & $1.85(82.6)$ \\
\hline Yes & $1.72(7.1)$ & $0.66(12.7)$ & $0.39(17.4)$ \\
\hline \multicolumn{4}{|l|}{ Diabetes } \\
\hline No & $21.48(88.5)$ & $4.08(78.6)$ & $1.74(77.7)$ \\
\hline Yes & $2.79(11.5)$ & $1.10(21.2)$ & $0.50(22.3)$ \\
\hline
\end{tabular}


JRRD, Volume 49, Number 3, 2012

Table 2. (cont)

Sociodemographic characteristics, healthcare, and health conditions of Veterans, Behavioral Risk Factors Surveillance System (BRFSS) survey (2003 and 2004), $n^{*}(\%)$.

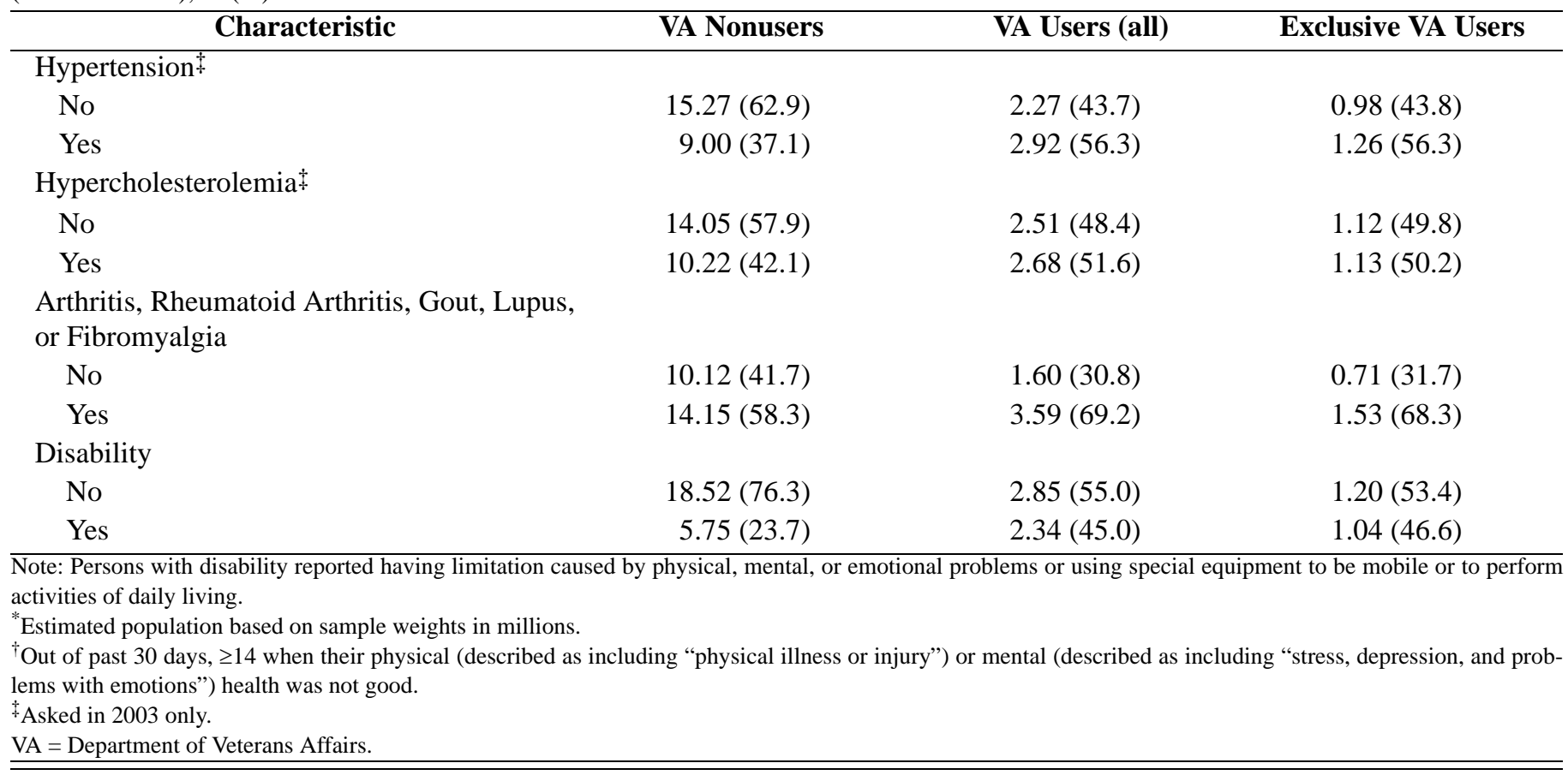

\section{RESULTS}

Overall, 568,506 adults were interviewed from all 50 states, the District of Columbia, Puerto Rico, the U.S. Virgin Islands, and Guam (264,684 in 2003 and 303,822 in 2004). Of this total, 79,365 identified themselves as Veterans. After excluding 5,610 individuals who did not provide information on receipt of VA care and 900 individuals who did not answer the questions on disability, 72,855 individuals comprised the study sample. A total of 58,436 were VA nonusers and 14,419 were VA users, of whom 6,476 used the VA exclusively for their healthcare.

Table 2 presents sociodemographic and health characteristics of VA nonusers, VA users, and exclusive VA users, who comprise approximately 45 percent of all VA users based on population estimates. Compared with VA nonusers, a greater proportion of VA users were $\geq 65$ years old; non-Hispanic black or other race; less educated; and divorced, separated, or widowed. These same differences were also apparent in exclusive VA users, with the exception of age, because a greater proportion of VA exclusive users were 50 to 64 years old. Compared with VA nonusers, a greater proportion of VA users, particularly those who received all healthcare from the VA, reported not having healthcare coverage, possibly because they did not consider the VA as one considers employer-provided healthcare. VA users were more likely to report fair or poor health, frequent poor physical or mental health, diabetes, hypertension, high cholesterol, and joint problems such as arthritis. The age- and sex-adjusted prevalence of disability among VA users was nearly double that of VA nonusers $(44.0 \%$ vs 23.2\%). In VA users, the prevalence of disability was greatest in those 50 to 64 years old, while it increased monotonically with age in VA nonusers (data not shown). The prevalence of disability was similar in men and women and greatest in non-Hispanic whites; those who had less than a high school education; were divorced, separated, or widowed; and had healthcare coverage and a regular healthcare provider. There was a clear gradient of disability by health status, with those reporting excellent health having a substantially lower prevalence of disability compared with those with poor health. Similarly, the prevalence of disability among individuals with diabetes, hypertension, or arthritis or joint pain was 14 to 33 percent more than in those without the condition.

The receipt of immunizations against influenza (VA users and nonusers: $p \leq 0.03$ ) and pneumococcus (VA nonusers: $p<0.001$, VA users: $p<0.10$ ) were greater in individuals with a disability (Figure 1). Obese men 


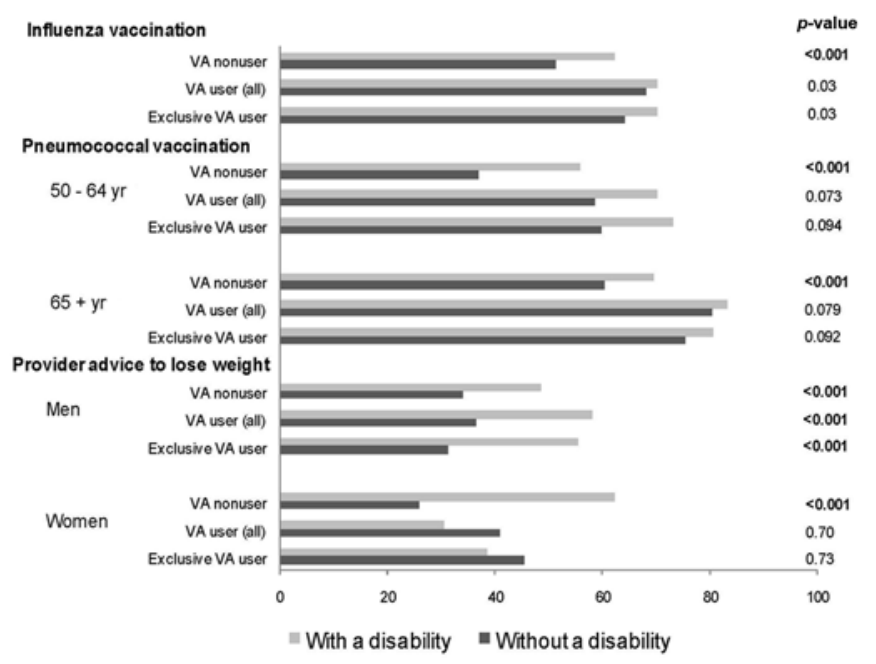

Figure 1.

Receipt of primary preventive services in relation to use of Department of Veterans Affairs (VA) care and disability status, Behavioral Risk Factors Surveillance System survey (2003 and 2004). Exclusive VA user refers to persons who reported receiving medical care only from VA facilities, while VA user (all) refers to exclusive VA users as well as persons who received care at VA facilities and elsewhere.

with a disability were significantly more likely to receive weight management counseling regardless of whether they were VA users or nonusers. However, while obese female VA nonusers with a disability were more likely to receive weight management counseling than those without a disability $(p<0.001)$, obese female VA users with a disability were less likely to receive weight management counseling, though estimates were imprecise because of small sample size ( $30.4 \%$ vs $40.8 \%, p=0.7$ ).

In terms of screenings involving procedures (Figure 2), the receipt of lower GI endoscopy varied depending on age and VA use. In persons 50 to 64 years old, receipt of lower GI endoscopy was greater in VA nonusers with a disability (51.7\% vs $47.6 \%, p=0.034$ ), while we found no differences in VA users related to disability (52.6\% vs $53.7 \%, p=0.99$ ). In Veterans who were $\geq 65$ years old, receipt of lower GI endoscopy was similar among VA nonusers with and without a disability (61.1\% vs $63.1 \%$, $p=0.26$ ), while we found a suggestion of greater receipt in VA users with a disability $(67.5 \%$ and $60.5 \%, p=$ 0.085 ). When we examined a composite measure of colorectal screening that incorporated both FOBT and lower GI endoscopy, there was little difference in receipt among VA users with and without a disability. However,

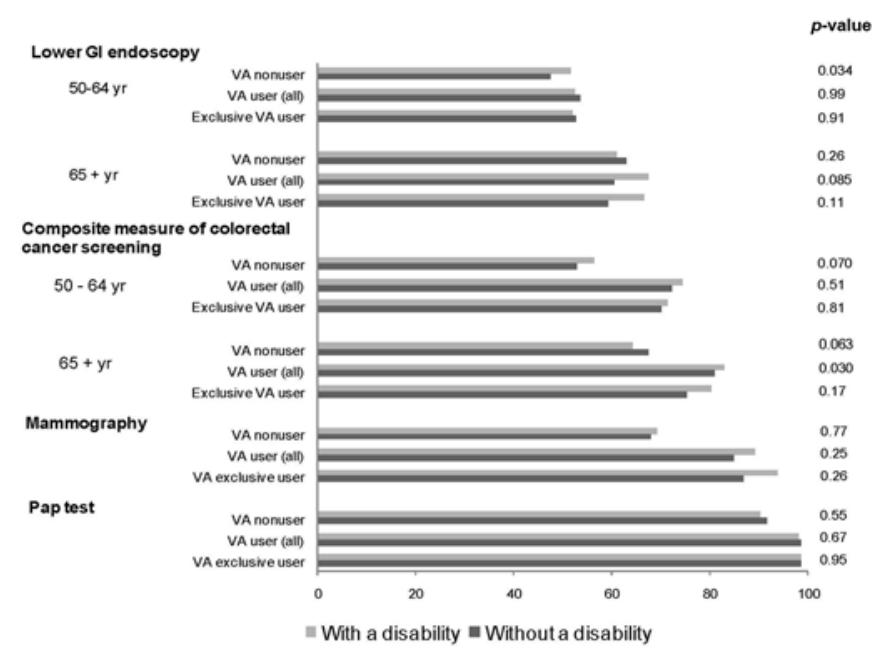

Figure 2.

Receipt of screening involving procedures in relation to use of Department of Veterans Affairs (VA) care and disability status, Behavioral Risk Factors Surveillance System survey (2003 and 2004). Exclusive VA user refers to persons who reported receiving medical care only from VA facilities, while VA user (all) refers to exclusive VA users as well as persons who received care at VA facilities and elsewhere. $\mathrm{GI}=$ gastrointestinal.

in VA nonusers, we found borderline evidence that in those 50 to 64 years old, persons with a disability were more likely to receive appropriate screening (56.4\% vs $52.9 \%, p=0.07$ ), while the opposite was true in those $\geq 65$ years old, with greater receipt among persons without a disability (64.4\% vs $67.5 \%, p=0.063)$. Appropriate receipt of screening for cervical cancer was relatively similar in Veterans with and without a disability (all $p \geq$ 0.55 and $<1.5 \%$ difference). For mammography in women $\geq 40$ years old, the differences between those with and without a disability were on the order of 4.5 to 6.9 percentage points in VA users, but only 1.3 percentage points in VA nonusers. Though no differences were statistically significant, the estimates indicated greater receipt in Veterans with a disability. In sensitivity analyses limited to women in the age range targeted by the VA performance measure for mammography (50 to 69 years old), the results were generally similar to those presented in Figure 2 (VA nonusers: $75.1 \%$ vs $70.7 \%, p=0.57$, and VA users: $93.8 \%$ vs $84.0 \%, p=0.097$, in those with vs without a disability, respectively).

FOBT and HIV testing were similar in those with and without a disability ( $p \geq 0.30$ in all groups, Figure 3 ). The frequency of serum cholesterol screening was greater in 


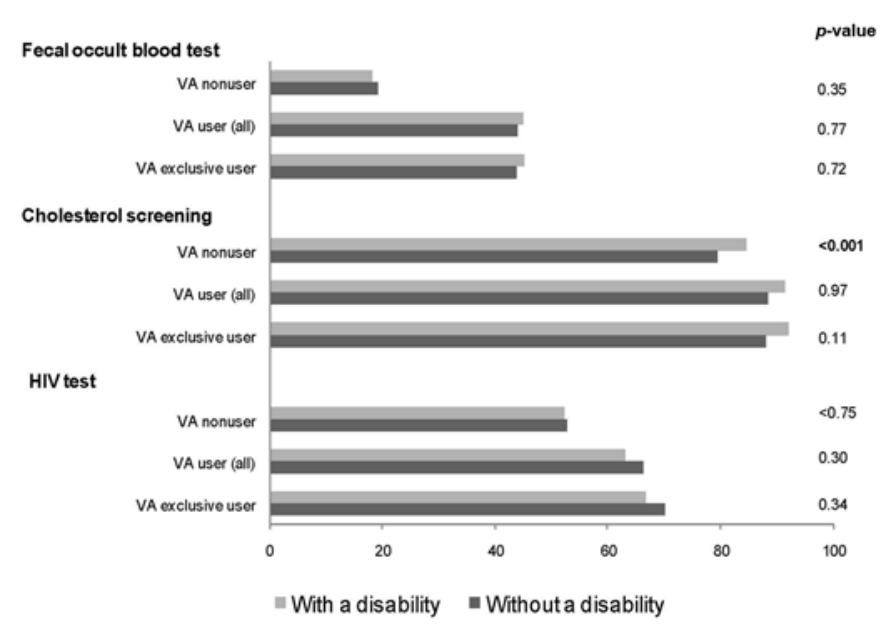

Figure 3.

Receipt of screening involving blood tests in relation to use of Department of Veterans Affairs (VA) care and disability status, Behavioral Risk Factors Surveillance System survey (2003 and 2004). Exclusive VA user refers to persons who reported receiving medical care only from VA facilities, while VA user (all) refers to exclusive VA users as well as persons who received care at VA facilities and elsewhere. HIV = human immunodeficiency virus.

persons with a disability, although the difference was only statistically significant in VA nonusers $(p<0.001)$.

\section{DISCUSSION}

The purpose of this study was is to examine whether there were disparities in the receipt of preventive services among individuals with a disability who obtained all, part, or none of their healthcare from the VA. Our results suggest that Veterans with a disability generally received recommended preventive healthcare services at frequencies equal to or greater than in Veterans without a disability, particularly for primary preventive services. These findings agree with results from previous studies that reported similar or greater receipt of immunizations and cholesterol screening in persons with versus those without a disability [10,13,39-40]. The greater prevalence of immunizations and cholesterol screening in persons with a disability may be a consequence of a condition (e.g., chronic cardiovascular or liver disease) that serves as an indication for vaccination or screening and/or that these same conditions lead to more care and thus create additional opportunities for the delivery of preventive services.

There was a suggestion of lower receipt of advice to lose weight in female VA users with a disability, although the difference was not statistically significant due to small numbers of obese female VA users with a disability, so caution should be excercised in interpreting our results. Some prior studies have found more [22,41] while others have found less $[23,42]$ frequent receipt of dietary and exercise advice among persons with a disability relative to those without. We do not know why female VA users with a disability were less likely to receive weight management counseling relative to female VA users without a disability, while no such disparities were apparent in female VA nonusers or male VA users or nonusers in relation to disability. The disabilities and/or coexisting conditions present in female VA users may differ from those present in male VA users and female VA nonusers, resulting in different rates of provider counseling. VA has demonstrated superior performance on preventive interventions included among VA performance measures $[7,43]$. Studies have found smaller or no differences for conditions not part of the performance monitoring system [44]. It was not until 2009 that obesity screening became a VA performance measure, but there is no performance measurement of weight management counseling. Future research is needed to assess the extent to which implementation of obesity screening affects weight management counseling across groups.

For cancer screening (i.e., lower GI endoscopy screening for colorectal cancer, mammography, and Pap tests), our results contrast with a number of prior studies conducted in non-VA users [9,11,13-14]. Unlike immunizations, mammography and lower GI endoscopies require an additional appointment; thus, it is unlikely that the similar receipt that was apparent for Veterans with a disability is solely a function of more visits. Instead, these results suggest that fewer barriers and more facilitators for cancer screening may exist for Veterans with a disability, particularly for those who receive care at the VA.

Care delivery systems within the VA and differences in the population studied (characteristics of Veterans vs non-Veterans) are possible explanations for the lack of disparity we observed in the current study. The healthcare delivery reforms undertaken by the VA in the late 1990s have been documented previously $[6,45]$. Some of the factors that may be relevant for the current findings include clinical reminders, increased accountability stemming 
from the use of performance measures, and the creation of dedicated special primary care clinics for women [46]. These broad-based quality improvement efforts may have resulted in parity in quality of preventive care for those with and without disabilities. Nonetheless, the VA initiatives cannot explain the findings in VA nonusers.

A second possible explanation is that the disabilities present in Veterans may differ from disabilities in nonVeterans because many disabilities present or acquired before adulthood render individuals ineligible for military service. Because the wording of the BRFSS questions only permitted us to define disability broadly, we were not able to investigate the timing, type, or severity of disability. Other studies have found that receipt of preventive care varied by the type and severity of a person's disability [9-10]; thus, it is possible that differences in the current study were obscured by lumping together all individuals with a disability. Despite these limitations, the definition of disability that we used has been shown to have explanatory power in previous studies [33,36]. Future studies that collect such information will be better suited to understand this heterogeneity.

Additional limitations of this study should be noted when interpreting our results. We relied on self-report of health services. Prior studies have found that sensitivity of self-report for cancer and serum cholesterol screening is relatively high, but specificity may be low except for colon cancer screening, where both sensitivity and specificity have been found to be high [47-49]. For a number of services such as vaccination, which are often administered outside of primary care settings, self-report is highly sensitive and moderately specific compared with medical records [50-52]. When we compared the BRFSS survey estimates to those obtained from VA sources derived from medical record review [45-46,53-54], estimates were similar, providing further evidence for confidence based on the self-reported data from the BRFSS survey. In any case, although there may be both random and systematic errors in reporting, it is unlikely that such errors would differ depending on disability. Additionally, we focused on process measures to assess quality of care. Therefore, we are unable to determine whether Veterans with and without a disability have equal outcomes.

Although the BRFSS is a large survey, precision of estimates in small subgroups (e.g., female Veterans) was limited. Furthermore, individuals who did not have landline telephones were excluded, such that generalizability to individuals who did not meet the eligibility criteria (e.g., cellular telephone-only households or homeless individuals) is limited. For cellular telephone-only households, it is difficult to determine how such selection might bias results. Cellular telephone-only households are likely to be younger and less likely to have a disability, but they also may be less likely to receive preventive care services, resulting in a potential overestimate of preventive care receipt in individuals without a disability. We would hypothesize that homeless individuals are more likely to have a disability and to not receive preventive care. While about 23 percent of homeless individuals are Veterans, the proportion of all Veterans who are homeless is small (approximately $<0.5 \%$ ) $[2,55]$. Thus, preventive care receipt estimates may be overestimated due to exclusion of homeless individuals, and this may be differential by disability and VA use status, but because of the small number of homeless individuals, the effect would likely be small and would be unlikely to affect conclusions.

Finally, the data from this study are somewhat dated. Unfortunately, more recent data on a national sample of Veterans to evaluate these questions was not available through the BRFSS surveys. Possible changes in delivery of health services and/or Veteran characteristics may mean that associations observed in 2003 and 2004 differ from those that would be observed currently.

\section{CONCLUSIONS}

In summary, the receipt of most preventive services was equal to or greater in Veterans with a disability relative to Veterans without a disability. While we observed marginal evidence for lower colorectal cancer screening in older VA nonusers and weight management counseling in obese female VA users, we found no evidence of lower receipt for Pap tests or mammography. In the past few years, the VA has begun to see a greater number of Veterans who have served in Iraq and Afghanistan, including an increasing number who have sustained injuries that have resulted in both physical and mental health problems. Ongoing evaluations of disparities in relation to disability are needed as the demographics of the VA change with the aging of Vietnam-era Veterans and influx of younger Veterans. Thus, the issue of preventive care services in relation to disabilities in Veterans will continue to be pertinent for the foreseeable future. 


\section{ACKNOWLEDGMENTS}

\section{Author Contributions:}

Study concept and design: A. J. Littman, T. D. Koepsell,

C. W. Forsberg, J. K. Haselkorn, E. J. Boyko.

Analysis and interpretation of data: A. J. Littman, T. D. Koepsell,

C. W. Forsberg, J. K. Haselkorn, E. J. Boyko.

Drafting of manuscript: A. J. Littman.

Critical revision of manuscript for important intellectual content:

A. J. Littman, T. D. Koepsell, C. W. Forsberg, J. K. Haselkorn,

E. J. Boyko.

Statistical analysis: C. W. Forsberg.

Obtained funding: T. D. Koepsell, E. J. Boyko.

Administrative, technical, or material support: A. J. Littman,

T. D. Koepsell, C. W. Forsberg, J. K. Haselkorn, E. J. Boyko.

Study supervision: A. J. Littman.

Financial Disclosures: The authors have declared that no competing interests exist.

Funding/Support: This material is based on work supported in part by the VA Office of Research and Development Cooperative Studies and Rehabilitation Research and Development Programs. Dr. Littman was supported by a VA Rehabilitation Research and Development Service Career Development Award (grant 6982).

Additional Contributions: Dr. Koepsell is now an emeritus professor in the Departments of Epidemiology and Health Services, University of Washington.

Institutional Review: Because BRFSS survey data are de-identified and in the public domain, this research was determined to be exempt from institutional review board review by the VA Puget Sound Institutional Review Board (MIRB 1542).

Participant Follow-up: The authors do not plan to inform participants of the publication of this study because of a lack of contact information.

\section{REFERENCES}

1. National Center for Health Statistics. Healthy people 2010. Hyattsville (MD): Centers for Disease Control and Prevention; 2010.

2. National Center for Veterans Analysis and Statistics. VA benefits \& health care utilization [Internet]. Washington (DC): Department of Veterans Affairs; 2010 [updated 2010 Apr 28]. Available from: http://www.va.gov/VETDATA/ Pocket-Card/4X6_spring10_sharepoint.pdf

3. Congress of the United States, Congressional Budget Office. Potential costs of veterans' health care. Washington (DC): Congressional Budget Office; 2010.

4. Doebbeling BN, Vaughn TE, Woolson RF, Peloso PM, Ward MM, Letuchy E, BootsMiller BJ, Tripp-Reimer T, Branch LG. Benchmarking Veterans Affairs Medical Centers in the delivery of preventive health services: Comparison of methods. Med Care. 2002;40(6):540-54.

PMID:12021680

http://dx.doi.org/10.1097/00005650-200206000-00011
5. Kizer KW, Demakis JG, Feussner JR. Reinventing VA health care: Systematizing quality improvement and quality innovation. Med Care. 2000;38(6 Suppl 1):I7-16. PMID:10843266

6. Jha AK, Wright SM, Perlin JB. Performance measures, vaccinations, and pneumonia rates among high-risk patients in Veterans Administration health care. Am J Public Health. 2007;97(12):2167-72. PMID:17971554

http://dx.doi.org/10.2105/AJPH.2006.099440

7. Ross JS, Keyhani S, Keenan PS, Bernheim SM, Penrod JD, Boockvar KS, Federman AD, Krumholz HM, Siu AL. Use of recommended ambulatory care services: Is the Veterans Affairs quality gap narrowing? Arch Intern Med. 2008; 168(9):950-58. PMID:18474759 http://dx.doi.org/10.1001/archinte.168.9.950

8. Desai MM, Rosenheck RA, Druss BG, Perlin JB. Mental disorders and quality of diabetes care in the Veterans Health Administration. Am J Psychiatry. 2002;159(9):1584-90. PMID:12202281 http://dx.doi.org/10.1176/appi.ajp.159.9.1584

9. Chevarley FM, Thierry JM, Gill CJ, Ryerson AB, Nosek MA. Health, preventive health care, and health care access among women with disabilities in the 1994-1995 National Health Interview Survey, Supplement on Disability. Womens Health Issues. 2006;16(6):297-312. PMID:17188213 http://dx.doi.org/10.1016/j.whi.2006.10.002

10. Diab ME, Johnston MV. Relationships between level of disability and receipt of preventive health services. Arch Phys Med Rehabil. 2004;85(5):749-57. PMID:15129399 http://dx.doi.org/10.1016/j.apmr.2003.06.028

11. Iezzoni LI, McCarthy EP, Davis RB, Siebens H. Mobility impairments and use of screening and preventive services. Am J Public Health. 2000;90(6):955-61. PMID:10846515 http://dx.doi.org/10.2105/AJPH.90.6.955

12. Ramirez A, Farmer GC, Grant D, Papachristou T. Disability and preventive cancer screening: Results from the 2001 California Health Interview Survey. Am J Public Health. 2005;95(11):2057-64. PMID:16195509 http://dx.doi.org/10.2105/AJPH.2005.066118

13. Wei W, Findley PA, Sambamoorthi U. Disability and receipt of clinical preventive services among women. Womens Health Issues. 2006;16(6):286-96. PMID:17188212 http://dx.doi.org/10.1016/j.whi.2006.09.002

14. Schenck AP, Peacock SC, Klabunde CN, Lapin P, Coan JF, Brown ML. Trends in colorectal cancer test use in the medicare population, 1998-2005. Am J Prev Med. 2009; 37(1):1-7. PMID:19423273 http://dx.doi.org/10.1016/j.amepre.2009.03.009

15. James TM, Greiner KA, Ellerbeck EF, Feng C, Ahluwalia JS. Disparities in colorectal cancer screening: A guidelinebased analysis of adherence. Ethn Dis. 2006;16(1):228-33. PMID:16599375 
16. Iezzoni LI, McCarthy EP, Davis RB, Harris-David L, O’Day B. Use of screening and preventive services among women with disabilities. Am J Med Qual. 2001;16(4):135-44. PMID:11477958 http://dx.doi.org/10.1177/106286060101600405

17. Smeltzer SC. Preventive health screening for breast and cervical cancer and osteoporosis in women with physical disabilities. Fam Community Health. 2006;29(1 Suppl): 35S-43S. PMID:16344635

18. Watts S. Access to cervical screening for women with learning disabilities. Br J Nurs. 2008;17(8):518-25. PMID:18563025

19. Kim DH, Sagar UN, Adams S, Whellan DJ. Lifestyle risk factors and utilization of preventive services in disabled elderly adults in the community. J Community Health. 2009;34(5):440-48. PMID:19517224 http://dx.doi.org/10.1007/s10900-009-9166-4

20. Ahmed NU, Smith GL, Haber G, Belcon MC. Are women with functional limitations at high risk of underutilization of mammography screening? Womens Health Issues. 2009;19(1):79-87. PMID:19111790 http://dx.doi.org/10.1016/j.whi.2008.09.001

21. Yano EM, Bastian LA, Frayne SM, Howell AL, Lipson LR, McGlynn G, Schnurr PP, Seaver MR, Spungen AM, Fihn SD. Toward a VA Women's Health Research Agenda: Setting evidence-based priorities to improve the health and health care of women veterans. J Gen Intern Med. 2006;21(Suppl 3):S93-101. PMID:16637953 http://dx.doi.org/10.1111/j.1525-1497.2006.00381.x

22. Galuska DA, Will JC, Serdula MK, Ford ES. Are health care professionals advising obese patients to lose weight? JAMA. 1999;282(16):1576-78. PMID:10546698 http://dx.doi.org/10.1001/jama.282.16.1576

23. Weil E, Wachterman M, McCarthy EP, Davis RB, O’Day $\mathrm{B}$, Iezzoni LI, Wee CC. Obesity among adults with disabling conditions. JAMA. 2002;288(10):1265-68.

PMID:12215134 http://dx.doi.org/10.1001/jama.288.10.1265

24. Grabois EW, Nosek MA, Rossi CD. Accessibility of primary care physicians' offices for people with disabilities. An analysis of compliance with the Americans With Disabilities Act. Arch Fam Med. 1999;8(1):44-51. PMID:9932071 http://dx.doi.org/10.1001/archfami.8.1.44

25. Gans BM, Mann NR, Becker BE. Delivery of primary care to the physically challenged. Arch Phys Med Rehabil. 1993;74(12 Spec No):S15-19.

26. Redelmeier DA, Tan SH, Booth GL. The treatment of unrelated disorders in patients with chronic medical diseases. N Engl J Med. 1998;338(21):1516-20. PMID:9593791 http://dx.doi.org/10.1056/NEJM199805213382106
27. Kroll T, Jones GC, Kehn M, Neri MT. Barriers and strategies affecting the utilisation of primary preventive services for people with physical disabilities: A qualitative inquiry. Health Soc Care Community. 2006;14(4):284-93. PMID:16787479 http://dx.doi.org/10.1111/j.1365-2524.2006.00613.x

28. Dobie DJ, Kivlahan DR, Maynard C, Bush KR, Davis TM, Bradley KA. Posttraumatic stress disorder in female veterans: Association with self-reported health problems and functional impairment. Arch Intern Med. 2004;164(4): 394-400. PMID:14980990 http://dx.doi.org/10.1001/archinte.164.4.394

29. Rabiner DJ, Branch LG, Sullivan RJ Jr. Patient factors related to the odds of receiving prevention services in Veterans Health Administration medical centers. Am J Manag Care. 1999;5(9):1153-60. PMID:10621081

30. Behavioral Risk Factor Surveillance System. Operational and user's guide. Atlanta (GA): Centers for Disease Control and Prevention; [updated 2006 Dec 12]. Available from: ftp://ftp.cdc.gov/pub/Data/Brfss/userguide.pdf

31. Behavioral Risk Factors Surveillance System. State questionnaire. Vol. 1.5. Atlanta (GA): Centers for Disease Control and Prevention; 2003 [updated 2002 Dec]. Available from: http:// www.cdc.gov/brfss/questionnaires/pdf-ques/2003brfss.pdf

32. Behavioral Risk Factor Surveillance System. Overview: BRFSS 2003. Atlanta (GA): Centers for Disease Control and Prevention; 2003.

33. Okoro CA, Strine TW, Balluz LS, Crews JE, Dhingra S, Berry JT, Mokdad AH. Serious psychological distress among adults with and without disabilities. Int J Public Health. 2009;54(Suppl 1):52-60. PMID:19363587

34. Brown DR, Yore MM, Ham SA, Macera CA. Physical activity among adults >or=50 yr with and without disabilities, BRFSS 2001. Med Sci Sports Exerc. 2005;37(4):620-29. PMID:15809561 http://dx.doi.org/10.1249/01.MSS.0000158189.17546.ED

35. McGuire LC, Strine TW, Okoro CA, Ahluwalia IB, Ford ES. Healthy lifestyle behaviors among older U.S. adults with and without disabilities, Behavioral Risk Factor Surveillance System, 2003. Prev Chronic Dis. 2007;4(1):A09. PMID:17173717

36. Armour BS, Swanson M, Waldman HB, Perlman SP. A profile of state-level differences in the oral health of people with and without disabilities, in the U.S., in 2004. Public Health Rep. 2008;123(1):67-75. PMID:18348482

37. Rosenbaum PR. Model-based direct adjustment. J Am Stat Assoc. 1987;82(398):387-94. http://dx.doi.org/10.2307/2289440

38. Rao JN, Scott AJ. On chi-squared tests for multiway contingency tables with cell proportions estimated from survey data. Ann Stat. 1984;12(1):46-60. http://dx.doi.org/10.1214/aos/1176346391 
39. Lavela SL, Weaver FM, Smith B, Chen K. Disease prevalence and use of preventive services: Comparison of female veterans in general and those with spinal cord injuries and disorders. J Womens Health (Larchmt). 2006;15(3):301-11. PMID:16620189 http://dx.doi.org/10.1089/jwh.2006.15.301

40. New York State Department of Health. Chartbook on disability in New York State, 1998-2000. Albany (NY): New York State Department of Health; 2002.

41. Fontaine KR, Haaz S, Bartlett SJ. Are overweight and obese adults with arthritis being advised to lose weight? J Clin Rheumatol. 2007;13(1):12-15. PMID:17278942 http://dx.doi.org/10.1097/01.rhu.0000256168.74277.15

42. Maclurg K, Reilly P, Hawkins S. Participation in general practice health screening by people with multiple sclerosis. Br J Gen Pract. 2004;54(508):853-55. PMID:15527612

43. Trivedi AN, Matula S, Miake-Lye I, Glassman PA, Shekelle P, Asch S. Systematic review: Comparison of the quality of medical care in Veterans Affairs and non-Veterans Affairs settings. Med Care. 2011;49(1):76-88.

PMID:20966778

http://dx.doi.org/10.1097/MLR.0b013e3181f53575

44. Asch SM, McGlynn EA, Hogan MM, Hayward RA, Shekelle P, Rubenstein L, Keesey J, Adams J, Kerr EA. Comparison of quality of care for patients in the Veterans Health Administration and patients in a national sample. Ann Intern Med. 2004;141(12):938-45. PMID:15611491

45. Jha AK, Perlin JB, Kizer KW, Dudley RA. Effect of the transformation of the Veterans Affairs Health Care System on the quality of care. N Engl J Med. 2003;348(22):2218-27.

PMID:12773650 http://dx.doi.org/10.1056/NEJMsa021899

46. Jha AK, Perlin JB, Steinman MA, Peabody JW, Ayanian JZ. Quality of ambulatory care for women and men in the Veterans Affairs Health Care System. J Gen Intern Med. 2005;20(8):762-65. PMID:16050889 http://dx.doi.org/10.1111/j.1525-1497.2005.0160.x

47. Rauscher GH, Johnson TP, Cho YI, Walk JA. Accuracy of self-reported cancer-screening histories: A meta-analysis. Cancer Epidemiol Biomarkers Prev. 2008;17(4):748-57. PMID:18381468 http://dx.doi.org/10.1158/1055-9965.EPI-07-2629

48. Martin LM, Leff M, Calonge N, Garrett C, Nelson DE. Validation of self-reported chronic conditions and health services in a managed care population. Am J Prev Med. 2000; 18(3):215-18. PMID:10722987 http://dx.doi.org/10.1016/S0749-3797(99)00158-0

49. Baier M, Calonge N, Cutter G, McClatchey M, Schoentgen S, Hines S, Marcus A, Ahnen D. Validity of self-reported colorectal cancer screening behavior. Cancer Epidemiol Biomarkers Prev. 2000;9(2):229-32. PMID:10698488
50. Jencks SF, Cuerdon T, Burwen DR, Fleming B, Houck PM, Kussmaul AE, Nilasena DS, Ordin DL, Arday DR. Quality of medical care delivered to Medicare beneficiaries: A profile at state and national levels. JAMA. 2000;284(13): 1670-76. PMID:11015797 http://dx.doi.org/10.1001/jama.284.13.1670

51. Mac Donald R, Baken L, Nelson A, Nichol KL. Validation of self-report of influenza and pneumococcal vaccination status in elderly outpatients. Am J Prev Med. 1999;16(3): 173-77. PMID:10198654 http://dx.doi.org/10.1016/S0749-3797(98)00159-7

52. Skull SA, Andrews RM, Byrnes GB, Kelly HA, Nolan TM, Brown GV, Campbell DA. Validity of self-reported influenza and pneumococcal vaccination status among a cohort of hospitalized elderly inpatients. Vaccine. 2007;25(25): 4775-83. PMID:17499402 http://dx.doi.org/10.1016/j.vaccine.2007.04.015

53. Brown DS, Kurlantzick VG, McCall NT, Williams TV, Gantt CJ, Granger E. Use of six clinical preventive services in TRICARE Prime compared to insured, managed care, and all U.S. populations and healthy people 2010. Prev Med. 2009;48(4):389-91. PMID:19254744 http://dx.doi.org/10.1016/j.ypmed.2009.02.016

54. Keyhani S, Ross JS, Hebert P, Dellenbaugh C, Penrod JD, Siu AL. Use of preventive care by elderly male veterans receiving care through the Veterans Health Administration, Medicare fee-for-service, and Medicare HMO plans. Am J Public Health. 2007;97(12):2179-85. PMID:17971544 http://dx.doi.org/10.2105/AJPH.2007.114934

55. National Coalition for Homeless Veterans. Background \& statistics. Washington (DC): National Coalition for Homeless Veterans; 2011 [updated 2012]. Available from: http:// nchv.org/background.cfm

Submitted for publication December 3, 2010. Accepted in revised form August 17, 2011.

This article and any supplementary material should be cited as follows:

Littman AJ, Koepsell TD, Forsberg CW, Haselkorn JK, Boyko EJ. Preventive services in veterans in relation to disability. J Rehabil Res Dev. 2012;49(3):339-50. http://dx.doi.org/10.1682/JRRD.2010.12.0229

ResearcherID: Alyson J. Littman, PhD, MPH: A-6409-2012

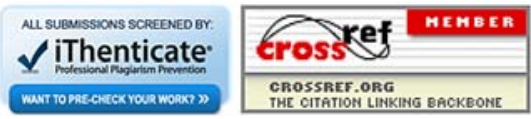

